\title{
The Degree of Practicing Distributed Leadership by Public Secondary School Principals in Amman Governorate and Its Relation to Teachers' Attitudes toward Work
}

\author{
Emilia M. Nukari ${ }^{1}$ \\ ${ }^{1}$ PhD. Educational Administration, Amman, Jordan \\ Correspondence: Emilia M. Nukari, PhD. Educational Administration, Amman, Jordan. E-mail: \\ EmiliaNukari@hotmail.com \\ Received: March 9, 2019 \\ Accepted: April 8, 2019 \\ Online Published: April 14, 2019 \\ doi:10.5539/mas.v13n5p34 \\ URL: https://doi.org/10.5539/mas.v13n5p34
}

\begin{abstract}
This study aimed at finding out the degree of practicing distributed leadership by public secondary school principals in Amman governorate and its relation to teachers' attitudes toward work. The sample of the study consisted of (347) male and female teachers. They were chosen by using stratified random sample method. The descriptive correlational methodology was used. A questionnaire was used to collect data, after finding it validity and reliability. The findings of the study showed that the degree of practicing distributed leadership by public secondary school principals in Amman governorate from teachers' point of view was low, The mean was (2.28) and a standard deviation of (0.23). The field of "vision, mission and goals" came in the first rank. Its mean was (2.31) and a standard deviation of (0.37). The field of leadership practices came in the final rank. The mean was (2.25) and a standard deviation of (0.35) and the level of teachers' attitudes toward work was low too. There was a positive significant correlational relationship at $(\alpha \leq 0.05)$ between the degree of practicing distributed leadership by public secondary school principals and the level of teachers' attitudes toward work. The Pearson correlation coefficient value was $(0.30)$.

The most important recommendations are: Conducting training courses on the distributed leadership of the principals of public secondary schools in Jordan. And that the Ministry of Education adopt the distributed leadership as a focal point in the evaluation process and the selection of school principals.
\end{abstract}

Keywords: distributed leadership, attitudes, secondary schools

\section{Introduction}

The successful educational leader is capable of investing the efforts of the human resources of teachers, administrators, students and parents to achieve the objectives of the educational process. In order for the educational leader to be effective, leadership responsibilities should be distributed to teachers and involved in decision making, and that they have a comfortable work environment that ensures that their attitudes toward work are improved. This encourages the smart leader to use the distributed leadership style, to ensure the success of the organization, With his keenness on the distribution of leadership responsibilities to teachers each according to his competence and abilities with continuous follow-up to them and provide the necessary support and encouragement and enhance their self-confidence by giving them confidence in their abilities. The performance of an institution may decline when the institution's leader assumes all administrative burdens and leadership responsibilities as he is the only one capable of accomplishing them. If these responsibilities are many, he may not be able to accomplish them all in accordance with the plan. This will inevitably affect the performance of the institution. Therefore, this study focuses on the importance of the school leader's understanding that the use of distributed leadership helps to raise the school's performance and success.

A survey was conducted of the teachers 'views on the degree of practicing distributed leadership by public secondary school principals in Amman governorate, and its impact on teachers' attitudes toward work, which is illustrated by the results of this study.

There has been a growing interest in the distributed leadership of educational institutions, because they have enhanced confidence in individuals and groups, in order to respond to the requirements of the policy and educational policies of these institutions and the continuous improvement in them. Distributed leadership opens 
the way for principals to carry out developmental practices for the school community through the adoption of strategies to support the vision of the school, its mission and objectives, which worked to solve the problem of individual managers to make decisions, by strengthening teachers capable of activating their leadership role, which leads to decentralization of the decision and increase the level of administrative accountability. Distributed leadership doesn't mean that the responsibility of the school leadership is delegated to the principal, but rather the absence of any responsible person. At the same time, the principal is asked to understand the relationship between the leadership and organizational structure of the school and its culture (Ajwa, 2012).

Distributed leadership is a promising theory that distributes leadership roles to teachers to do the work they are required to do in schools today. The distributed leadership focuses on the performance of school leaders and teachers. The leadership of the school is seen from the organizational level and not at the individual level in the distributed model. All school members are therefore unique potential experts and an important source of knowledge, experience and wisdom. From this perspective, organizational values, goals and culture indicate who leads and when they lead in a distributed model, to lead the school rather than the formal structure of the roles of the principal and the separate teachers (Street, 2011).

The distributed leadership was initially described as a new leadership structure supported by activity theory. The recognition of the importance of "official" site leaders and "informal" experts has led to the emergence of a new leadership concept as "a mixed leadership". The emphasis on K1-12 in the United States has led to the identification of the "redundant leadership" aspect that has been applied to school principals and the side - by side practice applies to teachers. The leadership review in the UK school sector identified four main characteristics of distributed leadership: "Focus on work rather than attitudes, consideration of the importance of the internal and external context, the culture of academic independence and support through professional development in a more collaborative approach to conflict resolution" (Jones \& Harvey, 2017).

Distributed leadership includes several individual activities to achieve educational development. The collaborative culture of the school is developed when the principal involves teachers in the planning and decision making process, and encourages them to participate in achieving the goals. Distributed leadership is the key component of human capacity building and improvement in schools because many individuals involved in distributed leadership are better aware of the tasks and problems the school faces (Bashir, Akram \& Lodhi, 2017).

What appears to be resistance to the culture of accountability and external controls, the Organization for Economic Cooperation and Development (OECD) (2008) suggests that school leaders can make a difference in the performance of the school and student if they are granted autonomy to make important decisions. Four leadership responsibilities have been identified as working to improve learning outcomes: (1) Support, evaluate and improve teacher quality, (2) Support for goal setting, evaluation and accountability, (3) Strengthen the management of strategic financial and human resources, which include supporting financial skills and engaging leaders in the employment of their teachers, (4) Adopting a systematic comparison of leadership policies and practices by encouraging collaboration without - of - school partners and distributing leadership responsibilities (Dampson, Havor \& Laryea, 2018).

Spillane and Diamond referred to in Sibanda (2018) described the distributed leadership as a cooperative and coordinated distribution that can be explained as follows:

- Collaborative leadership: Practices are common tasks for two or more leaders working together in a particular situation and their hidden talents and leadership skills are identified through cooperative action.

- Collective leadership: Two or more leaders work separately but ley on each other for the development of the school and take reciprocal roles. Sometimes the principal takes the leadership role and sometimes the teacher takes the role of the leader.

- Coordinated leadership: Leadership distribution includes a leadership routine that consists of two or more activities of leaders to be carried out in a particular sequence.

\section{Fields of distributed leadership}

Some researchers divided the distributed leadership into several fields, as each of them identified. Gordon (2010) identified the distributed leadership in four fields:

\section{- Vision, Mission and Goals:}

Vision means ambition that the educational institution wishes to reach in the future. The mission is the way through which the school's vision is achieved. The mission is based on school objectives. In order to practice effective distributed leadership within the school, its vision must be shared with clear mission and objectives. 


\section{- Shared responsibility:}

The shared responsibility of the principal requires that he has a high ability to organize teachers and recognize the existence of individual differences in terms of their interest, competencies, skills, career ambitions and experiences. The success of distributed leadership lies in the exchange roles in the school and the clarity of responsibilities and tasks. This requires the principal to create a stimulating environment for teachers to exercise leadership.

\section{- School culture:}

The culture of the school must be a result of the surrounding environment. The culture of the educational institution must be formed based on the values, habits and behavioral patterns of the surrounding community. Hence the importance of joint work between the school and the local community.

\section{- Leadership practices}

They mean the practices of the principal and school teachers in a systematic and highly productive manner so that teachers need guidance from the school principal as well as enabling them to coordinate their work and enhance their skills and knowledge.

From the above, it is the responsibility of the school principal to exercise distributed leadership and share roles and responsibilities with teachers. This is imperative to work to support teachers and meet their needs and improve their attitudes toward work, as well as push them to perform their duties with desire and love by them. This is what this study tried to find out what the impact of the distributed leadership on the attitudes of teachers toward work.

According to many studies, the attitude is a state of sentimental behavioral and cognitive reaction in a particular situation of the individual with his personal knowledge, experience and motives. To overcome the problems faced by teachers in the classroom, to provide quality education and to love the profession of education, positive attitudes are necessary, because if teachers lose respect for the teaching profession, it will affect education and outcomes in an unsuccessful educational environment. On the other hand, a positive relationship was found between attitudes, educational abilities and teacher satisfaction. In the studies conducted on the candidates for the teaching profession, it was noted that the positive attitudes affected the academic success of the students and achieve higher academic results. For this reason, positive attitudes toward the profession enable teachers to achieve greater academic success and raise students with achievements (Muhammet \& Okan, 2018).

Teachers who are responsible for many of the next generations of children need to show the true emotional qualities that may enable them to perform better. Business mentality includes attitudes, ideas and values related to work as a combination of society vision and individual vision. The mentality of the teacher at work expresses his attitudes toward it, and the way they see work as an accomplishment or obligatory duty. Satisfaction with work is an important part of professional life. It has implications on the personal and organizational levels. Job satisfaction is defined as a positive emotion derived from the employee's personal opinion about his job. Self - sufficiency is very important in the development of teachers because it is required in the decision - making process, in curriculum planning, in the educational process, in motivating students to learn and in the process of effective communication (Colomeischia \& Colomeischia, 2014).

Sprinthall, et.al. (1994) defined the attitude as a state of mind in which the individual controls his or her response positively or negatively towards people, situations and things.

\section{Characteristics of the attitudes}

Tiyab (2012) stated the following characteristics of attitudes as follows:

1. Attitudes are not made up of a vacuum, but they always involve a relationship between the individual and the subject of attitude.

2. The attitude is merely a virtual composition that implies its existence of behavior which is expressed verbally or situationally.

3. The attitude consists of three components: cognitive, emotional and behavioral, and notes among them impact and effect.

4. Some researchers consider the attitudes to be learned, not innate. While others view them as innate readiness, educated, and acquired. Other researchers defined them as inherited.

5. Attitudes allow to predict an individual's response to some social, psychological and educational stimuli.

6. Some see steady attitudes change relatively.

7. The attitude can be considered a tendency. Many social psychologists define the tendency as a positive 
attitude.

8. Attitudes are always located between two opposite sides, one positive and the other negative.

9. There is an overlap between attitude and behavior that affects each other.

\section{Attitudes components}

Social psychologists analyzed attitudes as an organizational structure consisting of three elements:

- Cognitive component: which is related to the availability of information, experience and culture in the individual to help him to supply knowledge and beliefs adopted toward an event. The cognitive component of the individual, which affects the construction of his point of view towards something that leads to the emotional component, which is based on cognitive process (Baosh, 2012).

- $\quad$ Affective component: This component is illustrated by the feelings of love and hatred of the individual toward a particular thing. The individual's interest in a specific subject is paid towards him in a positive way, but his hatred of a particular subject is paid towards him negatively (Witting, 2001).

- Behavioral component: Refers to the tendency of the individual behavior according to specific patterns towards the attitude subject (Bernstein, et.al. 2006).

\subsection{Study Problem}

And from the vital role of secondary school principals in the development of educational institutions and work to achieve their objectives, as well as the importance of the practice of distributed leadership, which focuses on strengthening the relationship between the leader and followers in educational institutions and the distribution of roles and responsibilities to serve the institution; and despite the research and studies on distributed leadership or attitudes, this study came to link the two variables, and it aimed to explore the degree of leadership practice distributed among the principals of the public secondary schools in the Amman governorate and its relation to the teachers' attitudes towards work, to provide a theoretical and practical framework for the distributed leadership by shedding light on its importance and its impact on the attitudes of teachers in secondary schools in Amman governorate.

In light of this, the problem of the current study was to answer the following question: What is the degree of practicing distributed leadership by public secondary school principals in Amman governorate and what its relationship to the teachers' attitudes toward work?

\subsection{Objective and Questions of the Study}

This study aimed at measuring the degree of practicing distributed leadership by public secondary school principals in Amman governorate and its relation to the teachers' attitudes toward work. The following questions arise from this objective:

1. What is the degree of practicing distributed leadership by public secondary school principals in Amman governorate from teachers' point of view?

2. What is the level of the teachers' attitudes toward work in governmental secondary schools in Amman governorate from their point of view?

3. Is there a significant correlational relationship at $(\alpha \leq 0.05)$ between the degree of practicing distributed leadership by public secondary school principals in Amman governorate and the level of teachers' attitudes toward work?

\subsection{Importance of the Study}

The importance of this study stems from the importance of information and ideas related to the practice of distributed leadership in schools and teachers' attitudes toward work, through which it is possible to work on the development of Jordanian schools. The educational system is essential to the progress of any country, so it is important to develop this system to follow the leadership methods that have proven to be effective. It is hoped that this study will benefit from its results the following entities:

- Jordanian Ministry of Education, by using the results of this study as a feedback, that identifies strengths in the application of distributed leadership in schools, and its relationship to increasing teacher attitudes toward work.

- Secondary school principals, in finding out their degree of practicing distributed leadership, and how to achieve the required level of practice, in order to increase teachers' attitudes toward work.

- Secondary school teachers: in finding out the level of their attitudes toward work, and the degree of their 
cooperation within one team.

- $\quad$ The scarcity of studies that highlight the relationship between the practice of distributed leadership among school principals and the increasing attitudes of teachers toward work, increases the importance of this study.

- $\quad$ This study provides two tools that are sure of their validity and reliability, that can be used in subsequent research.

\subsection{Terminology of Study}

The study adopts the following terms:

1.4.1 Distributed leadership: defined by Humphreys (2010) as: "the leadership that is based on the distribution of the administrative and educational tasks and responsibilities of the school to all its employees."

The researcher defined the distributed leadership as a modern administrative directive that assign school principals leadership roles to teachers, in order to achieve the goals of the school through their participation in decision making, as measured by the tool developed and used in this study.

1.4.2 The attitude: defined as an internal state of mind that controls the individual's response, negatively or positively, to people, attitudes and things (Sprinthall Sprinthall \& Oja, 1994).

The researcher defined teachers' attitudes toward work as: the tendency of the teachers and their willingness to interact with all elements of the educational environment in a positive or negative way, as measured by the tool developed and used in this study.

\subsection{Study Limits}

This study was limited to all public secondary school teachers in Amman governorate for the academic year (2018/2019).

\section{Previous Studies}

\subsection{Several Researchers Addressed the Issue of Distributed Leadership, from Them}

- $\quad$ Al - Sharifi and Abdullah (2017) conducted a study aimed at identifying the level of practicing distributed leadership by private secondary school principals in Amman governorate according to the following variables: sex, academic qualification and experience. The descriptive correlational methodology was used. A stratified random sample was drawn from the population of the study. The number of its members was (341) male and female teachers. A questionnaire was developed to measure the level of practicing distributed leadership by private secondary school principals from teachers' point of view. The findings of the study indicated that the level of practicing distributed leadership was medium. There were significant differences in the level of practicing distributed leadership attributed to sex variable, in favor of females.

- Saayma (2017) conducted a study to find out the degree of practicing distributed leadership by secondary school principals in Gaza governorates and it relation to some variables. Descriptive analytical methodology was used. A questionnaire was used to measure the degree of practicing distributed leadership. The sample of the study consisted of (134) principals and (220) teachers. The findings of the study showed that the degree of practicing distributed leadership by secondary school principals was medium. There were no significant differences of practicing distributed leadership attributed to sex, academic qualification and years of experience variables. While there were significant differences of practicing distributed leadership attributed to job title variable (Teacher - Principal) in favor of the principal.

- $\quad$ Al - Abadi (2017) carried out a study aimed at identifying the degree of practicing distributed leadership by governmental secondary school principals in Amman governorate, and its relation to the availability degree of the dimensions of learning organization, from teachers' point of view. The sample of the study consisted of (419) male and female teachers. They were selected by using a proportional stratified random sample method. Two questionnaires were used to collect data. The first was to measure the degree of practicing distributed leadership. The second was to measure the availability degree of the dimensions of learning organization. The most important findings of the study were: The degree of practicing distributed leadership by governmental secondary school principals in Amman governorate was medium, from teachers' point of view. The availability degree of the dimensions of learning organization in the governmental secondary schools in Amman governorate was medium.

- Özkan and Çakir (2017) conducted a study aimed at developing a scale to determine teachers' perceptions toward the level of distributed leadership in their schools. The sample of the study consisted of (868) teachers in the city center of Folterlin. Factor analysis and analysis of construction validity factor were applied. At the 
end of teaching for all, a model was obtained explaining (62.465\%) of the total variance. It consisted of five factors, of the formal structure, objectives of leadership, cooperation, trust, shared responsibility, encouragement and imitative. The results of confirmation factor (CFA) showed that the model with five factors had adequate relationships. The Cronbach Alpha formula was calculated with respect to the reliability of the scale. At the end of the analysis, the distributed leadership scale was accepted, because it is valid and reliable.

- Kiliçoglu (2018) conducted a study aimed at understanding democratic and distributed leadership, by teachers in their school, and exploring the relationship between democratic leadership and distributed leadership. The study also aimed at enriching and broaden the scientific implications for the democratic and distributed leaderships with regard to the connection between them, to deepen understanding of leadership. The correlational search design was used. The study sample included (462) teachers in secondary schools in the Eskisehir region in Turkey. The results of the study were as follows: Responsive teachers see the practice of democratic leadership at the medium level. The support and supervision were considered to be a distributed leadership function for the school leadership teams. The results of the study revealed a strong relationship between the democratic leadership and distributed leadership functions and the characteristics of the leadership team.

\subsection{With Regard to the Attitudes toward Work, Many Researchers have been Interested in this Subject Including}

- $\quad$ Ngidi (1995) conducted a study aimed at finding out the attitudes of teachers toward the profession in rural secondary schools. A questionnaire was used to measure the attitudes. The sample of the study consisted of (134) rural secondary school teachers from six schools, in Kwazulu - Natal. One of the most important results of the study is that secondary school teachers in rural areas have a negative attitude towards the profession. The study revealed that the personal characteristics of the teachers have no effect on their attitudes toward profession. The study also revealed the existence of significant differences in the emotional and cognitive components of teachers' attitudes, but there weren't any significant differences in the behavioral component.

- Bake'i and Kasab (2009) carried out a study aimed at identifying the attitudes of UNRWA school teachers in Irbid educational district toward the teaching profession, and find out whether these attitudes vary according to the variables of sex, experience, academic qualification and specialization. The sample of the study consisted of (331) male and female teachers. Attitudes scale toward teaching profession was used. The results of the study indicated that the attitudes of UNRWA teachers toward teaching profession were positive. There were significant differences in the attitudes of teachers toward teaching profession attributed to sex variable, in favor of the females, and experience and academic qualification in favor of teachers with more years' experience, and the highest qualification.

- Ben Zorka and Genad (2016) conducted a study aimed at identifying teachers' attitudes toward teaching methods and their relationship to academic achievement. The sample of the study included (22) teachers and (135) male and female students. The analytical descriptive methodology was used. The data were collected for the study by means of a questionnaire to measure teachers' attitudes toward teaching methods. One of the most important results is that teachers' attitudes toward the modern teaching profession were positive in general. There was a significant correlational relationship between teachers' attitudes toward modern teaching methods and the academic achievement.

- The purpose of this research that conducted by Akdemir (2018) is to determine the relationship between prospective teachers' self-efficacy beliefs and their attitudes toward the teaching profession. Correlational research model was used in this research. The sample of the research consisted of (312) students studying in different departments from the faculty of education/ Agri Ibrahim Çeçen University. Data were collected by the teacher self-efficacy beliefs scale and attitude scale towards teaching profession. The results of the analysis revealed that the self-efficacy beliefs of the prospective teachers were at the level of definitely believing and attitudes toward the teaching profession were mostly in agreement. Prospective teachers were found to have higher self-efficacy beliefs in terms of positive classroom environment, and low self-efficacy belief in academic development. There was a significant positive correlation between the self-efficacy of prospective teachers and their attitudes toward the teaching profession.

\subsection{Current Study Site from Previous Studies}

By reviewing the previous studies related to the current study, and to identify their theoretical literature and methodology, the researcher found the following: the studies that dealt with the distributed leadership was important, but these studies did not link the the distributed leadership with the teachers' attitudes toward work. In addition the methodological approach in these studies which varied between descriptive based on actual situation 
and Reality and analytical in addition to the developmental approach.

The researchers noted that there is a series of studies dealing with distributed leadership as synonymous with successful leadership, as in the study of Kiliçoglu (2018). Beside that most studies also recommended that school principals should be pay more attention to distributed leadership and share it with teachers and all staffs in the school, because of its clear impact on the success of the educational institution. The researcher benefited from previous studies in the preparation of the theoretical framework and enriching it with many ideas related to the distributed leadership and teachers attitudes which were the basics that helped them in constructing the study questionnaire.

\section{Method and Procedures}

\subsection{Methodology of the Study}

The descriptive - correlational methodology as the most appropriate approach to this study. The questionnaire was adopted as a means of collecting data for both distributed leadership and Teachers' attitudes.

\subsection{Study Society}

The population of the study consisted of all public secondary school principals in Amman governorate. The number of male teachers is (1589) teachers, and the number of female teachers is (2007) teachers.

\subsection{Study Sample}

A stratified random sample was drawn from the population of the study. The number of sample subjects was determined according to the scale of sample size of the population prepared by Krejcie and Morgan (Krejcie \& Morgan, 1970). The sample number was (347) teachers, with (152) male teachers and (195) female teachers.

\subsection{Study Variables}

They include the following variables:

- Independent variable: The degree of practicing distributed leadership by public secondary school principals in Amman governorate.

- $\quad$ Dependent variable: Teachers' attitudes to work in these schools.

\subsection{Study Tools}

To achieve the objectives of the study, two tools were used to answer the questions:

- The first tool (distributed leadership) to detect the degree of practicing distributed leadership by public secondary school principals in Amman governorate from teachers' point of view. The researcher developed the tool of the study through reference to the relevant theoretical literature and related studies, such as Boudreaux (2011), Abou Zer (2015), Al - Abadi (2017), and Saayma (2017) studies. The questionnaire included in its originally drafted (26) items that have been modified.

- The second tool: (teachers' attitudes toward work). The researcher developed the second tool by reference to the theoretical literature and the previous studies, such as the studies of Al - Hijawi (2011) and Bukei and Kassab (2010) studies. The questionnaire included (26) items which have been modified. Each item was given a weighted weight according to the five dimensional Likert scale to estimate the degree of distributed leadership practice and the level of teachers' attitudes toward work according to (always, frequently, sometimes, seldom, and never) alternatives, and digitally represented in the following order: 5, 4, 3, 2, 1 .

\subsection{Study Tools Validity}

The validity of the study tools was verified by using content validity, by presenting the two tools to three of the specialized referees in the educational sciences at the Jordanian public and private universities. They expressed their agreement to the items of the distributed leadership and teachers' attitudes toward work questionnaires. Some language modifications were made to some items of the two questionnaires.

\subsection{Study Instruments Stability}

To ensure the Stability of the study tools, the (test - retest) method was applied, by applying each tool to a sample of (20) male and female teachers from outside the study sample. Two weeks later the application was re-applied to the same sample. The Pearson correlation coefficient was extracted between the two applications. The value of the correlation coefficient indicates that the two instruments have an appropriate Stability.

The internal consistency coefficient of the study tools was found by using (Cronbach - Alpha) formula. The values of Stability coefficient are acceptable in educational and psychological research as shown in the following: 
First: Stability of distributed leadership as shown in Table (1).

Table 1. Stability coefficients for study tool paragraphs using the Cronbach Alpha test

\begin{tabular}{cccc}
\hline No. & Field & Test-retest method & Internal consistency \\
\hline 1 & Vision, mission and goals & 0.77 & 0.83 \\
2 & School culture & 0.80 & 0.87 \\
3 & Leadership practices & 0.79 & 0.81 \\
& Total score & $\mathbf{0 . 8 4}$ & $\mathbf{0 . 8 9}$ \\
\hline
\end{tabular}

Second: Teachers' attitudes toward work

The correlation coefficient by (test-retest) method was (0.84) and in internal consistency method was $(0.89)$.

\subsection{Statistical Treatment}

Means, standard deviations and ranks were used for the first two questions.

Pearson correlation coefficient was used for the third question and referenced to the statistical tables to find out the significance of the correlation coefficient value.

\subsection{Correction of the Two Questionnaires}

The following equation has been adopted in determining the degree of practicing distributed leadership by public secondary school principals in Amman governorate, and also to determine the level of teachers' attitudes toward work in those schools:

\begin{tabular}{|c|l|l|l|l|}
\hline \multicolumn{2}{|l|}{ The higher value of the alternative - Minimum value of the alternative } \\
\hline $5-1$ & $=$ & 4 \\
\hline 3 & & 3 & 1.33 & \\
\hline
\end{tabular}

So the low degree is from $(1-2.33)$

Medium degree is from $(2.34-3.67)$

High degree is from $(3.68-5)$

\section{The Results of the Study}

4.1 The Results of The Answer to The First Study Question That States: What Is the Degree of Practicing Distributed Leadership by Public Secondary School Principals in Amman Governorate from Teachers' Point of View?

To answer this question, means, standard deviations and ranks were extracted, as shown in Table (2).

Table 2. Means, standard deviations and ranks for distributed leadership fields of governmental secondary school principals in Amman governorate from teachers' point of view

\begin{tabular}{cccccc}
\hline No. & Field & Mean & Standard deviation & Rank & Degree \\
\hline 1 & Vision, mission and goals & 2.31 & 0.37 & 1 & Low \\
2 & School culture & 2.26 & 0.33 & 2 & Low \\
3 & Leadership practices & 2.25 & 0.35 & 3 & Low \\
& Total score & $\mathbf{2 . 2 8}$ & $\mathbf{0 . 2 3}$ & - & Low \\
\hline
\end{tabular}

It is noted from table (2) that the degree of practicing distributed leadership by pubilc secondary school principals in Amman governorate from teachers' point of view was low. The mean was (2.28) and a standard deviation of (0.23). The field of "vision, mission and goals" came in the first rank. Its mean was (2.31) and a standard deviation of (0.37). The field of leadership practices came in the final rank. The mean was (2.25) and a standard deviation of $(0.35)$.

In terms of each field, the results were as follows: 
4.1.1 First: The first field: Vision, mission and goals. Table (3) clarifies that.

Table (3). Means, standard deviations and ranks for the items of "vision, mission and goals" field in descending order

\begin{tabular}{|c|c|c|c|c|c|}
\hline $\begin{array}{c}\text { Item } \\
\text { No. }\end{array}$ & Item & Mean & S.D. & Rank & Degree \\
\hline 1 & $\begin{array}{l}\text { The school administration sets a vision, mission and clear goals } \\
\text { for the school. }\end{array}$ & 2.46 & 0.87 & 1 & Medium \\
\hline 3 & Parents understand school mission. & 2.43 & 0.87 & 2 & Medium \\
\hline 2 & Teachers understand the school's vision, mission and goals. & 2.41 & 0.89 & 3 & Medium \\
\hline 5 & $\begin{array}{l}\text { The school administration prepares an annual plan that includes } \\
\text { all activities that validate the school's vision and mission. }\end{array}$ & 2.37 & 0.97 & 4 & Medium \\
\hline 4 & Students can describe the school's vision. & 2.27 & 0.98 & 5 & Low \\
\hline 6 & $\begin{array}{l}\text { The school sets a developmental plan to evaluate the goals } \\
\text { achieved. }\end{array}$ & 2.20 & 0.95 & 6 & Low \\
\hline 8 & Teachers determine their goals in light of school goals and vision. & 2.18 & 0.92 & 7 & Low \\
\hline \multirow[t]{2}{*}{7} & $\begin{array}{l}\text { The school curriculum is consistent with the school's vision and } \\
\text { mission. }\end{array}$ & 2.10 & 0.89 & 8 & Low \\
\hline & Total score & 2.31 & 0.37 & - & Low \\
\hline
\end{tabular}

It is noted from table (3) that the mean for the field of vision, mission and goals was low, as it reached (2.31) and a standard deviation of (0.37). The items of this field came in the medium and low degrees. The means ranged between $(2.46-2.10)$. Item (1) that states "The school administration sets a vision, mission and clear goals for the school" obtained the first rank. Its mean was (2.46) and a standard deviation of $(0.87)$ with a medium degree, while item (7) that states "The school curriculum is consistent with the school's vision and mission" came in the final rank. Its mean was (2.10) and a standard deviation of (0.89) with a low degree.

4.1.2 Second: School culture field. Table (4) shows that.

Table (4). Means, standard deviations and ranks for the items of "School culture" field in descending order

\begin{tabular}{clcccc}
\hline $\begin{array}{c}\text { Item } \\
\text { No. }\end{array}$ & Mean & Item. & Rank & Degree \\
\hline 14 & $\begin{array}{l}\text { The school principal encourages teachers to innovate by } \\
\text { accepting new ideas. }\end{array}$ & 2.47 & 0.83 & 1 & Medium \\
16 & $\begin{array}{l}\text { The principal focuses on school activities that serve the } \\
\text { community. }\end{array}$ & 2.46 & 0.84 & 2 & Medium \\
15 & 2.44 & 0.83 & 3 & Medium \\
10 & $\begin{array}{l}\text { The school principal has educational issues. } \\
\text { The principal believes in the ability of teachers to improve } \\
\text { students' level. }\end{array}$ & 2.23 & 0.90 & 4 & Low \\
11 & $\begin{array}{l}\text { The principal gives his full confidence to the teachers. } \\
\text { The principal creates a climate of mutual respect and } \\
\text { confidence among teachers. }\end{array}$ & 2.21 & 0.83 & 5 & Low \\
13 & $\begin{array}{l}\text { The principal provides appropriate resources to make full } \\
\text { contribution. }\end{array}$ & 2.10 & 0.87 & 6 & Low \\
12 & $\begin{array}{l}\text { The principal encourages teachers to share their experiences } \\
\text { to improve school teaching strategies. }\end{array}$ & 2.03 & 0.83 & 8 & Low \\
Total score & $\mathbf{2 . 2 6}$ & $\mathbf{0 . 3 3}$ & - & Low \\
\hline
\end{tabular}

It is noted from table (4) that the mean for the field of "School culture" was low, as it reached (2.26) and a standard deviation of (0.33). The items of this field came in the medium and low degrees. The means ranged from (2.472.03). Item (14) that states "The school principal encourages teachers to innovate by accepting new ideas" came in the first rank. Its mean was (2.47) and a standard deviation of (0.83) with a medium degree. While item (12) that states "The principal encourages teachers to share their experience to improve school teaching strategies" came in the final rank. Its mean was (2.03) and a standard deviation of $(0.83)$ with a low degree. 


\subsubsection{Third: Leadership practices. Table (5) clarifies that.}

Table (5). Means, standard deviations and ranks for the items of "leadership practices" field in descending order

\begin{tabular}{|c|c|c|c|c|c|}
\hline $\begin{array}{l}\text { Item } \\
\text { No. }\end{array}$ & Item & Mean & S.D. & Rank & Degree \\
\hline 17 & $\begin{array}{l}\text { The school principal allocates leadership tasks to the teachers in } \\
\text { accordance with his/ her ability. }\end{array}$ & 2.49 & 0.78 & 1 & Medium \\
\hline 20 & $\begin{array}{l}\text { The school principal involves teachers in solving educational } \\
\text { problems. }\end{array}$ & 2.35 & 0.94 & 2 & Medium \\
\hline 23 & $\begin{array}{l}\text { The principal conducts periodic meetings with teachers to discuss } \\
\text { educational issues. }\end{array}$ & 2.28 & 0.88 & 3 & Low \\
\hline 25 & The principal opens channels of communication with teachers. & 2.23 & 0.92 & 4 & Low \\
\hline 22 & $\begin{array}{l}\text { The principal provides time for teachers to carry out the leadership } \\
\text { tasks entrusted to them. }\end{array}$ & 2.23 & 0.92 & 4 & Low \\
\hline 26 & $\begin{array}{l}\text { The principal holds professional training workshops for teachers' } \\
\text { development. }\end{array}$ & 2.23 & 0.99 & 4 & Low \\
\hline 19 & $\begin{array}{l}\text { The principal sets up course schedule in collaboration with } \\
\text { teachers. }\end{array}$ & 2.22 & 0.92 & 7 & Low \\
\hline 24 & The principal provides feedback to teachers for their development. & 2.21 & 0.90 & 8 & Low \\
\hline 18 & $\begin{array}{l}\text { The principal involves teachers in making decisions about school } \\
\text { development. }\end{array}$ & 2.18 & 0.89 & 9 & Low \\
\hline 21 & $\begin{array}{l}\text { The principal provides the necessary facilities to facilitate the } \\
\text { leadership tasks of teachers. }\end{array}$ & 2.16 & 0.85 & 10 & Low \\
\hline & Total score & 2.25 & 0.35 & - & Low \\
\hline
\end{tabular}

Table (5) shows that the mean for the field of "leadership practices" was low. It reached (2.25) and a standard deviation of (0.35). The items of this field came in the medium and low degrees. Their means ranged from (2.49 - 2.16). Item (17) that states "The school principal allocates leadership tasks to the teachers in accordance with his/ her ability" came in the first rank. Its mean was (2.49) and a standard deviation of $(0.78)$ with a medium degree. Item (21) that states "The principal provides the necessary facilities to facilitate the leadership tasks of teachers" came in the final rank. Its mean was (2.16) and a standard deviation of (0.85) with a low degree.

4.2 The Results of The Answer to The Second Study Question That States: What Is the Level of The Teachers' Attitudes Toward Work in Public Secondary Schools in Amman Governorate from Their Point of View?

Table (6) shows that.

Table (6). Means, standard deviations and ranks for the items of teachers' attitudes toward work in governmental secondary schools in Amman governorate from their point of view in descending order

\begin{tabular}{clrrrr}
\hline $\begin{array}{c}\text { Item } \\
\text { No. }\end{array}$ & \multicolumn{1}{c}{ Item } & Mean & S.D. & Rank & Degree \\
\hline 26 & I am satisfied with the teachers' long vacations. & 2.58 & 0.88 & 1 & Medium \\
1 & I feel proud of my profession as a teacher. & 2.53 & 0.89 & 2 & Medium \\
24 & I feel confident when I stand in front of my class. & 2.52 & 0.91 & 3 & Medium \\
5 & My school administration provides me with continuous self - & 2.49 & 0.89 & 4 & Medium \\
& development. & 2.49 & 0.87 & 4 & Medium \\
14 & I would like to collaborate with my colleagues. & 2.48 & 0.89 & 6 & Medium \\
3 & My school administration feels job security. & 2.48 & 0.83 & 6 & Medium \\
11 & I continuously develop my performance. & 2.47 & 0.78 & 8 & Medium \\
10 & I do my best to accomplish the tasks entrusted to me. & 2.45 & 0.87 & 9 & Medium \\
4 & I have the ability to solve my problems. & 2.45 & 0.84 & 9 & Medium \\
9 & Be sure to arrive on time. & 2.44 & 0.84 & 11 & Medium \\
7 & I participate in school activities willingly. & 2.44 & 0.83 & 11 & Medium \\
8 & I encourage my students to choose a teaching career. & 2.44 & 0.88 & 11 & Medium \\
25 & I see that the profession of education is desirable from many & & & & \\
\hline
\end{tabular}




\section{people.}

6

I prefer to stay in the education profession, even if given the opportunity to move to another career.

22 I would like to share experiences with teachers.

15 I attend training courses organized by the school.

18 I am late after work to complete my school work.

20 I cut off my leave if the school interests so require.

23 I try to be as good as my principal.

13 I respect my school principal.

16 I feel fun while teaching students.

19 I participate in volunteer work at school.

2 I don't feel the time when I am in school.

12 Be sure to follow every new in my career.

17 I miss the school when I miss it.

21 I see that my work matches my specialty.

\begin{tabular}{cccc}
2.42 & 0.88 & 14 & Medium \\
2.42 & 0.89 & 14 & Medium \\
2.40 & 0.88 & 16 & Medium \\
2.40 & 0.88 & 16 & Medium \\
2.40 & 0.90 & 16 & Medium \\
2.39 & 0.85 & 19 & Medium \\
2.38 & 0.81 & 20 & Medium \\
2.38 & 0.82 & 20 & Medium \\
2.37 & 0.82 & 22 & Medium \\
2.36 & 0.81 & 23 & Medium \\
2.35 & 0.87 & 24 & Medium \\
2.34 & 0.89 & 25 & Medium \\
2.33 & 0.83 & 26 & Low \\
$\mathbf{2 . 4 3}$ & $\mathbf{0 . 2 5}$ & - & Medium \\
\hline
\end{tabular}

It is noted from table (6) that the mean for the level of teachers' attitudes toward work in public secondary schools in Amman governorate from their point of view was medium. It reached (2.43) and a standard deviation of (0.25). Item (26) that states "I am satisfied with the teachers' long vacations", cam in the first rank. Its mean was (2.58) and a standard deviation of (0.88) with a medium degree. While item (21) that states "I see that my work matches my specialty" came in the final rank". Its mean was (2.33) and a standard deviation of (0.83) with low degree.

4.3 The Results of the Answer of the Third Study Question That States: Is There a Significant Correlational Relationship At $(A \leqslant 0.05)$ Between The Degree of Practicing Distributed Leadership by Public Secondary School Principals In Amman Governorate and the Level Of Teachers' Attitudes Toward Work?

To answer this question Pearson correlation coefficient was found between the total score of the distributed leadership and its fields, and the total score of teachers' attitudes toward work questionnaire. Table (7) clarifies the results of this question.

Table (7). Pearson correlation coefficient between the degrees of practicing distributed leadership by pubic secondary school principals in Amman governorate and the level of teachers' attitudes toward work

\begin{tabular}{lcccc}
\hline Distributed & $\begin{array}{c}\text { Vision, mission } \\
\text { and goals }\end{array}$ & $\begin{array}{c}\text { School } \\
\text { culture }\end{array}$ & $\begin{array}{c}\text { Leadership } \\
\text { practices }\end{array}$ & $\begin{array}{c}\text { Total score for } \\
\text { distributed } \\
\text { leadership }\end{array}$ \\
$\begin{array}{l}\text { Attitudes toward work } \\
\begin{array}{l}\text { Total score for attitudes toward } \\
\text { work. }\end{array}\end{array}$ & 0.26 & 0.40 & -0.011 & 0.30 \\
Level of significance & 0.000 & 0.000 & 0.844 & 000 \\
\hline
\end{tabular}

Table (7) shows that there was a positive significant correlational relationship between the total score of distributed leadership and the total score of the level of teachers' attitudes toward work. Pearson correlation coefficient value was (0.30). The correlations between the total score of the level of teachers' attitudes toward work and the fields of distributed leadership, except leadership practices field.

\section{Results Discussion}

Discussion of the results related to answering the first question: What is the degree of practicing distributed leadership by public secondary school principals in Amman governorate from teachers' point of view?

The results of the study in table (2) showed that the degree of practicing distributed leadership by public secondary school principals in Amman governorate, from teachers' point of view was low. Its mean was (2.28) with a standard deviation of (0.23). The field of "vision, mission and goals" came in the first rank. This result may be attributed to the keenness of the school principal that the educational objectives emanate from the school's vision and mission, but he lacks to deal with educational developments in light of that vision and mission. 
In addition to not involving the school administration of teachers in setting up the vision and mission and that the school administration does not have a vision and a clear mission and goals.

The field of "school culture" came in the second rank. Its mean was (2.26) and a standard deviation of (0.33). This result may be attributed to the fact that the school principal does not encourage the exchange of visits and experiences between teachers, may not work to activate learning communities, does not organize training workshops, and does not depart from traditional teaching, as well as the lack of an appropriate school environment through which the exchange of ideas and information.

While the field of "leadership practices" came in the third and final rank. Its mean was (2.25) and a standard deviation of (0.35). This result may be attributed to the actions and practices of the principal to improve the leadership role of teachers, but not the level required. This result may be due to the fact that the principal does not encourage teachers to perform administrative or leadership tasks.

Discussion of the results related to answering the second question: What is the level of teachers' attitudes toward work in public secondary schools in Amman governorate from their point of view?

The results in table (6) showed that the mean of teachers' attitudes toward work in public secondary schools in Amman governorate, from their point of view was medium. It was (2.43) and a standard deviation of $(0.25)$. This result may be attributed to teachers having some privileges that may make their attitudes tend to be positive, such as their satisfaction with vacations, especially summer vacation. Teachers' attitudes may be affected by some of the situations and procedures they face within the school, which may create a gap between the work they do and their specialties such as the teacher of Arabic language teaching vocational science and sports education, which may affect their attitudes negatively.

Discussion of the results related to answering the third question: Is there a significant correlational relationship at $(\alpha \leq 0.05)$ between the degree of practicing distributed leadership by public secondary school principals in Amman governorate and the teachers' attitudes toward work?

The results in table (7) indicated that there was a significant correlational relationship at $(\alpha \leq 0.05)$ between the degree of practicing distributed leadership by public secondary school principals and the level of teachers' attitudes toward work. The Pearson correlation coefficient was $(0.30)$ at $(0.000)$ level of significance. This result may be attributed to the fact that the higher the degree of practicing distributed leadership, the higher the level of teachers' attitudes toward work.

\section{Recommendations}

In light of the results of the study the researcher recommended the following:

1. Organizing training courses on the distributed leadership of the principals of public secondary schools in Jordan.

2. Participation of public secondary school principals in seminars, conferences and workshops dealing with distributed leadership.

3. Ministry of Education will adopt distributed leadership as an important topic in the evaluation and selection process for secondary school principals.

4. Organizing workshops for governmental secondary school principals to familiarize them with the attitudes of teachers toward work.

5. Conducting a similar study of the current study on private secondary schools and compare its results with the results of the current study.

\section{References}

\section{Arabic References}

Ajwa, A. M. (2012). Distributed leadership: An applied study on elementary schools. Egyptian Journal for commercial studies, 36(1), 1-30.

Al - Abadi, M. A. (2017). Distributed leadership of governmental secondary school principals and its relation to the availability of the learning organization dimensions from teachers' point of view in the capital of Amman governorate (Unpublished Master Thesis). The Middle East University, Amman, Jordan.

$\mathrm{Al}$ - Hajawi, R. Z. (2011). The level of human relations practiced by the principals of private secondary schools in the capital Amman and its relation to the attitudes of teachers toward the profession (Unpublished Master Thesis). The Middle East University, Amman, Jordan. 
Al - Sharifi, A., Mahdi, A., \& Abdullah, E. M. (2017). The distributed leadership of private secondary school principals in Amman governorate from teachers' point of view. Mu'tah for Research and Studies, 32(4), 1342.

Bake'i N., \& Al - Kasab, A. (2010). UNRWA teachers' attitudes in Irbid educational area toward teaching career in light of some variables, An - Najah University Journal. Human Sciences, 24(2), 333-361.

Ben Zorka, S., \& Genad E. (2016). Attitudes of elementary school teachers toward teaching methods and their relation to academic achievement: Field study in primary Bahasi Bahbah, Jelfa State (Unpublished Master Thesis). University of Xi' an Ashour, Jelfa, Algeria.

Saayma, S. M. (2017). The degree of practicing distributed leadership by secondary school principals in Gaza governorates. Journal of Al-Quds Open University for Educational \& Psychological Research \& Studies, 6(20), 213-231.

Tiyab, M. (2012). The attitude towards the teaching profession and its relation to teaching performance among the teachers of physical education and sports in secondary education. Academy for Social and Human Studies, (8), 135-146.

\section{English References}

Akdemir, O. A. (2018). An Investigation of the relationship between prospective teachers' self - efficacy beliefs and their attitudes towards teaching profession. Journal of Education and e-Learning Research, 5(3), 157164 .

Bashir, I., Akram, M., \& Lodhi, H. (2017). Impact of distributed leadership and psychological empowerment on organizational learning culture. Journal of Educational Research, 20(2), 239-256.

Bernstein, D. P., Stewart A. L., \& Roy, E. (2006). Psychology (7th ed.). Boston: Houghton Mifflin Company.

Colomeischia, A., A., \& Colomeischia, T. (2014). Teachers' Attitudes towards work in relation with emotional intelligence and self - efficacy. Social and Behavioral Sciences, 159, 615-619, https://doi.org/10.1016/j.sbspro.2014.12.435.

Dampson, D. G., Havor, F. M., \& Laryea, P. (2018). Distributed leadership an instrument for school improvement: The study of public senior high chools in Ghana. Journal of Education and e-Learning research, 5(2), 79-85. https://doi.org/10.20448.

Gordon, R. D. (2010). Dispersed leadership: exploring the impact of antecedent forms of power using a communicative framework". Management Communication Quarterly, 24(1), 260-287. https://doi.org/10.1177/0893318909360213.

Humphreys, E. (2010). Distributed leadership and its impact on teaching and learning. Education Doctorate. NUI Maynooth, Ireland.

Jones, S., \& Harvey M. (2017). A distributed leadership change process model for higher education. Journal of $\begin{array}{lllll}\text { higher education policy and } & \text { 39(2), }\end{array}$ 139. https://doi.org/10.1080/1360080X.2017.1276661

Kilicoglu, D. (2018). Understanding democratic and distributed leadership: how democratic leadership of school principals related to distributed leadership in schools? Educational policy analysis and strategic research, 13(3), 6-23.

Krejcie, R. V., \& Morgan, D. W. (1970). Determining sample size for research activities. Educational and Psychological Measurement, 30(3), 607-610.

Muhammet, B., \& Sarigoz, O. (2018). An examination of teacher candidates' attitudes towards teaching profession. International Journal of Educational Administration and Policy Studies, 10(4), 25-32. https://doi.org/10.5897/IJEAPS2018.0553.

Ozkan, M., \& Cakir, C. (2017). Development of distributed leadership scale. International Journal of Eurasia Social Sciences, 8(30), 1629-1660.

Sibanda, L. (2018). Distributed leadership in three diverse public schools: Perceptions of deputy principals in Johannesburg. Issues in Educational Research, 28(3), 781-796.

Sprinthall, N., Sprinthall, R., \& Oja, S. (1994). Educational psychology a developmental approach (6th ed.). New York, R.R. Donnelly \& Sons Company.

Street, G. W. (2011). Engaging Staff in the Development of Distributed Leadership. A dissertation submitted in 
partial fulfillment of the requirements for the degree of doctor of education. Washington State University, USA.

Wittig, A. (2001). Introduction to psychology (2nd ed.). New York, Mc Graw-Hill.

\section{Copyrights}

Copyright for this article is retained by the author(s), with first publication rights granted to the journal.

This is an open-access article distributed under the terms and conditions of the Creative Commons Attribution license (http://creativecommons.org/licenses/by/4.0/). 